Security Studies

\title{
Soldiers, Civilians, and Multilateral Humanitarian Intervention
}

\section{Stefano Recchia}

To cite this article: Stefano Recchia (2015) Soldiers, Civilians, and Multilateral Humanitarian Intervention, Security Studies, 24:2, 251-283, DOI: 10.1080/09636412.2015.1036626

To link to this article: http://dx.doi.org/10.1080/09636412.2015.1036626

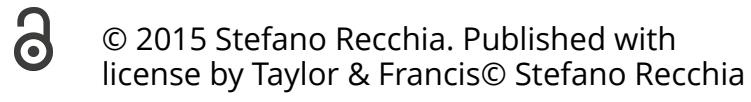

曲 Published online: 22 Jun 2015.

Submit your article to this journal ๘

Џ Article views: 1882

Q View related articles ¿

$\bigodot_{\text {crossnatk }}$ View Crossmark data ¿

蚂

Citing articles: 1 View citing articles $\square$ 


\title{
Soldiers, Civilians, and Multilateral Humanitarian Intervention
}

\author{
STEFANO RECCHIA
}

\begin{abstract}
Approval from the United Nations or NATO appears to have become a necessary condition for US humanitarian military intervention. Conventional explanations emphasizing the pull of legitimacy cannot fully account for this given that US policymakers vary considerably in their attachment to multilateralism. This article argues that America's military leaders, who are consistently skeptical about humanitarian intervention and tend to emphasize its costs, play a central role in making multilateral approval necessary. As long as top-ranking generals express strong reservations about intervention and no clear threat to US national security exists, they can veto the use of force. In such circumstances, even heavyweight "bumanitarian hawks" among the civilian leadership, who initially may have wanted to bypass multilateral bodies to maximize US freedom of action, can be expected to recognize the need for UN or NATO approval-if only as a means of mollifying the generals by reassuring them about the prospect of sustained multilateral burden sharing. Two case studies drawing on interviews with senior civilian and military officials illustrate and probe the plausibility of the argument.
\end{abstract}

In late February 2011, after Libyan strongman Muammar Qaddafi launched a brutal crackdown on local insurgents, national security leaders in the Barack Obama administration began debating the possibility of humanitarian military

(c) Stefano Recchia

This is an Open Access article. Non-commercial re-use, distribution, and reproduction in any medium, provided the original work is properly attributed, cited, and is not altered, transformed, or built upon in any way, is permitted. The moral rights of the named author(s) have been asserted.

Stefano Recchia is lecturer in international relations at the University of Cambridge. Further information about his research can be found at www.stefanorecchia.net. 
intervention. At one end of the policy spectrum were senior civilian officials of liberal Wilsonian persuasion-including National Security Council (NSC) staffers, Samantha Power and Benjamin Rhodes, as well as ambassador to the United Nations, Susan Rice-who vigorously called for military action; at the other end were secretary of defense, Robert Gates, and the top military leaders who opposed intervention by highlighting attendant risks and potential long-term operational costs. ${ }^{1}$ President Obama waited until 17 March before deciding in favor of intervention. ${ }^{2}$ By then, NATO allies, led by Britain and France, had pledged that they would carry most of the operation's burden after the initial degradation of Libyan air defenses. ${ }^{3}$ Furthermore, on that same day, the United Nations Security Council adopted Resolution 1973, authorizing NATO allies "to take all necessary measures ... to protect civilians and civilian populated areas under threat of attack." The Libya intervention is part of a pattern: since the end of the Cold War, the United States has used military force for humanitarian purposes numerous times, including in Northern Iraq (1991), Somalia (1992), Haiti (1994), Bosnia (1994-95), and Kosovo (1999); in each case, prior to intervention, policymakers secured approval from the United Nations Security Council (UNSC) or NATO's North Atlantic Council (NAC), as well as concrete burden-sharing commitments from international partners.

Securing UNSC or NAC approval is often time consuming; it constrains US freedom of action; it may require substantial side payments and logrolling; and it entails a loss of secrecy and thus typically eliminates the element of surprise. Policymakers can therefore be expected to seek such approval only if they anticipate that the benefits will outweigh the costs. The conventional wisdom is that US civilian leaders have either internalized or at any rate feel bound by norms of legitimate behavior, which demand that "in situations other than self-defense, decisions to use force must be made multilaterally." However, standard explanations emphasizing the pull of legitimacy norms cannot fully account for why the approval of standing international

\footnotetext{
${ }^{1}$ Christopher S. Chivvis, Toppling Qaddafi: Libya and the Limits of Liberal Intervention (Cambridge: Cambridge University Press, 2014), 44-53; Robert M. Gates, Duty: Memoirs of a Secretary at War (New York: Knopf, 2014), 511-12; Karen De Young and Craig Whitlock, "U.S. Defense Leaders Warn of Risks in Enforcing No-Fly- Zone," Washington Post, 2 March 2011.

${ }^{2}$ Gates, Duty, 518; Scott Wilson and Joby Warrick, "Obama's Shift Toward Military Action," Washington Post, 19 March 2011.

${ }^{3}$ When NATO took over command and control of the mission on 31 March, Gates declared before Congress that "this transition was part of the package and part of the plan with our allies, from day one." Operation Odyssey Dawn and the Situation in Libya. Hearing before the Senate Armed Services Committee, 112th Congress, 12 (31 March 2011) (statement of Robert M. Gates, US Secretary of Defense).

${ }^{4}$ Christian Reus-Smit, "Liberal Hierarchy and the License to Use Force," in Force and Legitimacy in World Politics, ed. David Armstrong, Theo Farrell, and Bice Maiguashca (New York: Cambridge University Press, 2005), 71. See also Thomas Risse-Kappen, "Between a New World Order and None: Explaining the Reemergence of the United Nations in World Politics," in Critical Security Studies, ed. Keith Krause and Michael C. Williams (Minneapolis: Minnesota University Press, 1997); Martha Finnemore, The Purpose of Intervention: Changing Beliefs About the Use of Force (Ithaca, NY: Cornell University Press, 2003), 80-82;
} 
organizations (IOs) such as the UN or NATO has apparently become a necessary condition for US humanitarian military intervention. Policymakers in the United States vary considerably in their attachment to multilateralism and consequently in the degree to which they are willing to accept potentially costly constraints on US freedom of action for the sake of IO legitimation.

Civilian policymakers who view humanitarian intervention as a matter of urgency (I call them "humanitarian hawks") often do not feel bound by norms requiring IO approval. When confronted with humanitarian crises abroad involving mass atrocities, war crimes, or ethnic cleansing, and when international partners do not share the same sense of urgency, the humanitarian hawks may initially be inclined to bypass multilateral bodies such as the UNSC and NATO's NAC to ensure swift military action. More dovish policymakers can be expected to place greater importance on IO approval, as a source of legitimacy and a catalyst for domestic and international support. Yet among US civilian leaders, the interventionist hawks tend to carry disproportionate weight: in the face of a worsening humanitarian situation, they have common morality on their side, and they can appeal to America's sense of exceptionalism and unique responsibility. Furthermore, the civilian doves may lack the professional expertise to effectively challenge the hawks' optimistic assessment about the risks and likely operational costs of intervention.

It is in this context that the top-ranking generals and admirals play an important restraining role. Senior US military officers are consistently more skeptical than civilian policymakers about deploying American forces abroad for human rights-related purposes. ${ }^{5}$ As the prospect of intervention becomes increasingly real, top-level military leaders - the chairman and vice chairman of the Joint Chiefs of Staff (JCS), the commanders of the unified combatant commands, and senior officers on the Joint Staff-typically request clear objectives, a viable exit strategy, and assurances that the operational burden will be shared with international partners. ${ }^{6}$ Because of their informational advantage and the military's high standing in American society, these top-level officers wield an extraordinary amount of influence over decisions regarding armed intervention. As long as they express strong reservations, and the civilian leadership is divided over whether to intervene (which is likely absent

\footnotetext{
Ian Hurd, After Anarchy: Legitimacy and Power in the UN Security Council (Princeton, NJ: Princeton University Press, 2007).

5 Ole R. Holsti, "Of Chasms and Convergences: Attitudes and Beliefs of Civilians and Military Elites at the Start of the New Millennium," in Soldiers and Civilians: The Civil-Military Gap in American National Security, ed. Peter D. Feaver and Richard H. Kohn (Cambridge, MA: MIT Press, 2001), 34-46; Peter D. Feaver and Christopher Gelpi, Choosing Your Battles: American Civil-Military Relations and the Use of Force (Princeton, NJ: Princeton University Press, 2004), chap. 2.

${ }^{6}$ Holsti, "Of Chasms and Convergences," 36-38, 84-87; Thomas Szayna et al., The Civil-Military Gap in the United States: Does It Exist, Why, and Does It Matter? (Santa Monica, CA: RAND, 2007), 101-3. See also Richard K. Betts, American Force: Dangers, Delusions, and Dilemmas in National Security (New York: Columbia University Press, 2012), chap. 9.
} 
clear threats to US national security), they can tilt the bureaucratic balance of power toward nonintervention, thus vetoing the use of force. ${ }^{7}$ In such circumstances, even the most heavyweight humanitarian hawks among the civilian leadership are likely to come to recognize the need for UN or NATO approval-if only as a means of mollifying the senior military officers by reassuring them about the prospect of sustained multilateral burden sharing.

My argument is not that the uniformed leaders' role is always decisive in steering US policy on humanitarian intervention toward the UNSC or NATO's NAC. Civilian policymakers may have other, independent motives for seeking IO approval—whether complying with international norms, reducing international opposition, or increasing US public support for intervention. ${ }^{8}$ However, the central hypothesis of this article is that, perhaps counterintuitively, military leaders constitute the ultimate bulwark against US unilateral humanitarian intervention. The uniformed leaders are likely to play a particularly salient role in multilateralizing coercive humanitarian operations that aim to resolve a humanitarian crisis at its roots. Given the difficulties of securing IO approval for such intrusive missions, hawkish civilian officials may at first be especially tempted to bypass multilateral bodies altogether; however, those are precisely the types of interventions that the American military is most likely to oppose in the absence of credible assurances about sustained multilateral burden sharing.

Scholarship on civil-military relations has long emphasized that, although US generals and admirals are reluctant to intervene abroad in pursuit of internal political change absent clear threats to national security, when the civilian leadership orders them to do so, their preference is for deploying "overwhelming force" with as much autonomy as possible. ${ }^{9}$ One

\footnotetext{
${ }^{7}$ Deborah D. Avant, "Are the Reluctant Warriors Out of Control? Why the US Military is Averse to Responding to Post-Cold War Low-Level Threats," Security Studies 2, no. 2 (Winter 1996-97): 51-90; Michael C. Desch, Civilian Control of the Military (Baltimore: Johns Hopkins University Press, 1999), 22-33; Andrew J. Bacevich, "Elusive Bargain: The Pattern of US Civil-Military Relations Since World War II," in The Long War: A New History of US National Security Policy Since World War II, ed. Bacevich (New York: Columbia University Press, 2007), 248-49.

${ }^{8}$ On how IO approval may help reduce international opposition to US policies, see Erik Voeten, "The Political Origins of the UN Security Council's Ability to Legitimize the Use of Force," International Organization 59, no. 3 (Summer 2005): 527-57; Alexander Thompson, "Coercion Through IOs: The Security Council and the Logic of Information Transmission," International Organization 60, no. 1 (Winter 2006): 1-34; Joel H. Westra, "Cumulative Legitimation, Prudential Restraint, and the Maintenance of International Order," International Studies Quarterly 54, no. 2 (June 2010): 513-33. On IO approval as a means to increase US public support, see especially Joseph M. Grieco et al., "Let's Get a Second Opinion: International Institutions and American Public Support for War," International Studies Quarterly 55, no. 2 (June 2011): 563-83; Terrence L. Chapman, Securing Approval: Domestic Politics and Multilateral Authorization for Force (Chicago: University of Chicago Press, 2011).

${ }^{9}$ Samuel P. Huntington, The Soldier and the State: The Theory and Politics of Civil-Military Relations (Cambridge, MA: Harvard University Press, 1957), 66-79; Richard K. Betts, Soldiers, Statesmen, and Cold War Crises, 2nd ed. (New York: Columbia University Press, 1991); David H. Petraeus, "Military Influence and the Post-Vietnam Use of Force," Armed Forces \& Society 15, no. 4 (Summer 1989): 490-93; Feaver and Gelpi, Choosing Your Battles, 43-53.
} 
might infer from this that senior officers should be suspicious of multilateral constraints. During the Korean War, General Douglas MacArthur in fact bemoaned "United Nations restrictions," complaining that they made it more difficult for the United States to employ force effectively and decisively. ${ }^{10}$ More recently, uniformed leaders have been wary of deploying US troops under foreign command and subjecting them to international jurisdiction. ${ }^{11}$ However, America's senior officers ultimately appear to be pragmatists on the question of multilateralism, and there is evidence that on average they value international cooperation through bodies like the UN or NATO more than civilian leaders. ${ }^{12}$

This article proceeds in four parts. The first part highlights the burdensharing benefits of IO approval and clarifies why civilian policymakers vary in their cost-benefit analysis vis-à-vis multilateralism. The second part discusses the senior military's skepticism about humanitarian intervention and related demand for burden sharing and exit strategies. The third part theorizes how the military's reluctance to intervene makes IO approval necessary and elaborates on the circumstances under which the military's role is likely to be particularly salient. The final part traces the process of US decision making on the Haiti (1993-94) and Kosovo (1998-99) interventions, drawing on dozens of interviews with senior civilian and military officials, in order to illustrate and probe the plausibility of the argument.

\section{IO APPROVAL FOR SUSTAINED BURDEN SHARING}

Advance approval from the UNSC or NAC legitimizes US military intervention and helps the United States signal benign intentions to foreign audiences. That reduces international opposition, making it easier for the leaders of third-party states to cooperate actively with the United States by offering landing and basing rights or contributing troops and resources. ${ }^{13}$ Although only a few major allies possess the ability to substantially contribute to USled combat operations in terms of advanced warfighting capabilities, many more foreign partners possess the more basic capabilities required for burden sharing on postwar stabilization and reconstruction. The legitimation effect of IO approval, however, may be insufficient by itself to ensure sustained

\footnotetext{
${ }^{10}$ Douglas MacArthur, Reminiscences (New York: Ishi Press, 2010), 372. See also William Manchester, American Caesar: Douglas MacArthur 1880-1964 (New York: Back Bay Books, 2008), 637, 667.

${ }^{11}$ Sarah B. Sewall, "Multilateral Peace Operations," in Multilateralism and US Foreign Policy, ed. Stewart Patrick and Shepard Forman (Boulder, CO: Lynne Rienner, 2002), 191-224.

${ }^{12}$ Holsti, "Of Chasms and Convergences," 36-38; Szayna et al., Civil-Military Gap, 101-3. See also Betts, American Force, 208-11.

13 Thompson, "Coercion Through IOs." See also Jennifer Welsh, "Authorizing Humanitarian Intervention," in The United Nations and Global Security, ed. Richard Price and Mark Zacher (New York: Palgrave, 2004); Chapman, Securing Approval, chap. 5.
} 
international burden sharing following the end of major combat. This is when multilateral pledges of support and their reputational implications become relevant. First, the resolution authorizing military intervention, typically a UNSC mandate, may commit the multilateral body to set up a follow-on peacekeeping force led by other international partners. For instance, Security Council (SC) Resolution 940, which authorized the 1994 intervention in Haiti, explicitly mandated the establishment of a follow-on UN force as soon as basic security in the country had been restored. ${ }^{14}$ Consequently, half a year after the initial intervention, the United States was able to hand off peacekeeping responsibilities to a six-thousand-strong UN mission, composed of a majority of non-US troops. ${ }^{15}$ Similarly, SC Resolution 1497, authorizing a US-led intervention in Liberia in 2003, included a commitment on the part of the Security Council "to establish . . . a follow-on United Nations stabilization force" under regional leadership (i.e., led by countries other than the United States) within a maximum of two months. ${ }^{16}$ This mode of proceeding is particularly attractive for lower-stakes humanitarian missions, in which reliance on less proficient troops from developing countries appears acceptable for keeping the peace. ${ }^{17}$

Second, the burden-sharing commitment may be less formal. A SC resolution authorizing the use of "all necessary means" involves a public, and therefore potentially costly, commitment to support US policy on the part of all those council members who have offered their affirmative vote. The same goes for approval from NATO's NAC, which requires a consensus among all members of the alliance. Once member states are thus committed to supporting US policy, they are less likely to subsequently resist the establishment of UN or NATO stabilization missions. Countries other than the United States may also independently value institutions such as the UN and NATO for the security benefits they provide. Consequently, once a UN or NATO stabilization mission has been approved and the IO's reputation becomes linked to mission success, member states may be willing to maintain significant troop contributions even in the face of mounting costs. Approval of US-led interventions by NATO's NAC, in particular, substantially increases Washington's ability to extract sustained burden-sharing contributions from its most militarily capable allies. As former NATO secretary-general Jaap de

\footnotetext{
${ }^{14}$ United Nations Security Council (SC), Resolution 940, "UN Mission in Haiti," 31 July 1994, par. 8.

15 David M. Malone, Decision-Making in the UN Security Council: The Case of Haiti, 1990-1997 (New York: Oxford University Press, 1997), chap. 7.

${ }^{16}$ SC, Resolution 1497, "Liberia," 1 August 2003, par. 2.

${ }^{17}$ SC, Resolution 2085, authorizing a French intervention in Mali in 2012, followed the same pattern in mandating the establishment of a follow-on stabilization mission made up largely of African troops.
} 
Hoop Scheffer explains, "The sense of keeping one's obligations and commitments to other allies, upon whom one's own security ultimately depends, is a powerful motive for equitable burden-sharing." 18

In the Balkans, for instance, where the United States intervened in 1995 and again in 1999 only after securing IO approval, Washington's European partners have remained committed to the success of NATO operations that they supported from the outset and have taken on increasingly greater shares of the stabilization and reconstruction burden. ${ }^{19}$ By contrast, should the United States launch military interventions that are not clearly in self-defense without UN or NATO approval, any support that it may be able to elicit from improvised coalitions of the willing is likely to be fickle and shortlived. The American and British experience in Iraq from 2003 to 2011 is an eloquent case in point. After the 2003 invasion, launched without IO approval, Washington and London struggled to persuade other countries to contribute stabilization troops. Once the United States agreed to offset part of the financial costs of those contributions, in the short run, it was able to recruit about sixteen thousand troops from partners other than Britain. ${ }^{20}$ But the improvised coalition showed little staying power, disintegrating as the operation became protracted and casualties mounted. By May 2007, when America surged its own troops to more than one hundred fifty thousand at the height of the Iraqi civil war, the non-US, non-UK component had shrunk to only about seven thousand troops, making up less than five percent of the total international force. ${ }^{21}$

\section{Policymakers' Differing Cost-Benefit Analyses}

In an important contribution to theory, Sarah Kreps argues that two factors determine whether the United States seeks multilateral approval for military intervention: (1) its time horizon, as determined by the overall sense of

\footnotetext{
${ }^{18}$ Jaap de Hoop Scheffer, Project Syndicate, 18 June 2008, http://www.project-syndicate.org/ columnist/jaap-d-scheffer. See also Sarah Kreps, "Elite Consensus as a Determinant of Alliance Cohesion: Why Public Opinion Hardly Matters for NATO-led Operations in Afghanistan," Foreign Policy Analysis 6, no. 3 (July 2010): 191-215.

${ }^{19}$ Steven Woehrel, "Future of the Balkans and US Policy Concerns," CRS Report for Congress (Washington, DC: Congressional Research Service, 2009), 9-13; Stefano Recchia, "Beyond International Trusteeship: EU Peacebuilding in Bosnia and Herzegovina," Occasional Paper No. 66 (Paris: EU Institute for Security Studies, 2007).

${ }^{20}$ Paul Richter, "US Enlists More Countries in Iraq, at Taxpayers' Expense," Los Angeles Times, 22 June 2003. See also Randall Newnham, "Coalition of the Bribed and Bullied?' US Economic Linkage and the Iraq War Coalition," International Studies Perspectives 9, no. 2 (May 2008): 183-200.

21 Stabilizing and Rebuilding Iraq: Coalition Support and International Donor Commitments. Hearings before the House Subcommittee on IOs, Human Rights, and Oversight, 110th Cong., 5-8 (9 May 2007) (statement of Joseph A. Christoff, director, International Affairs and Trade, US Government Accountability Office). See also Christopher M. Blanchard and Catherine Marie Dale, "Iraq: Foreign Contributions to Stabilization and Reconstruction," CRS Report for Congress (Washington, DC: Congressional Research Service, 2007), 11-18.
} 
urgency and (2) the anticipated operational commitment, "which refers to the level of resources directed toward the particular intervention." 22 When time horizons are long, reflecting low urgency, and the United States anticipates a significant operational commitment, multilateralism will seem attractive "as a way to reassure other states [and] share ... costly burdens." Conversely, when time horizons are short, reflecting a strong sense of urgency (based on the perception that important American interests are threatened), and the United States "thinks it can win quickly or on the cheap, ... there will be fewer incentives to aggregate resources," and we can expect a unilateral course of action. Kreps argues that time horizons as determined by sense of urgency "tend to dominate" because a high sense of urgency reduces concerns about operational commitment. ${ }^{23}$

Sometimes the value of the variables identified by Kreps may be so obvious that policymakers quickly reach a consensus on whether the longerterm burden-sharing benefits of securing IO approval are likely to outweigh short-term freedom of action costs. Perhaps more often than not, however, decision makers debating the merits of intervention under the pressure of rapidly evolving circumstances differ significantly in their sense of urgency and their expectation of the likely operational commitment. ${ }^{24}$ As Stephen Brooks notes, since the sense of urgency and consequently "the discount rate may vary from one policy maker to another in ways that cannot be explained simply by looking at the objective nature of the security environment," policymakers' cost-benefit analysis vis-à-vis multilateralism is also likely to vary. This leads Brooks to conclude that "more research is needed on this topic." 25

\section{CIVILIAN HUMANITARIAN HAWKS VERSUS MILITARY DOVES}

Humanitarian and other human rights-related interventions typically reflect classical liberal-internationalist, or Wilsonian, beliefs in individual freedom, self-government, and national self-determination. ${ }^{26}$ Accordingly, within the

\footnotetext{
${ }^{22}$ Sarah E. Kreps, Coalitions of Convenience: United States Military Interventions After the Cold War (New York: Oxford University Press, 2011), 31, 28-33, more generally.

${ }^{23}$ Ibid., 35, 33, 34.

${ }^{24}$ For instance, there was no consensus among US leaders as to whether the 1994 Haitian governance and refugee crisis, the large-scale ethnic violence in the Balkans following the breakup of Yugoslavia, or even Iraq's suspected WMD proliferation around the turn of the millennium required urgent military action.

${ }^{25}$ Stephen Brooks, "Review of Sarah Kreps, Coalitions of Convenience: United States Military Interventions After the Cold War," H-Diplo/ISSF Roundtable 4, no. 7 (2012): 7.

${ }^{26}$ Michael W. Doyle, The Question of Intervention (New Haven, CT: Yale University Press, 2015), chap. 4; Stefano Recchia, "The Origins of Liberal Wilsonianism," in Just and Unjust Military Intervention: European Thinkers from Vitoria to Mill, ed. Recchia and Jennifer Welsh (New York: Cambridge University Press, 2013).
} 
executive branch, civilian policymakers of liberal Wilsonian persuasion as well as their neoconservative kin (usually officials from the State Department and the staff of the National Security Council) tend to push most strongly for humanitarian military intervention. ${ }^{27}$ Liberal Wilsonianism is sympathetic to international institutions in the abstract, while neoconservatism is ideologically inimical to most forms of multilateral cooperation. ${ }^{28}$ However, those principled differences between liberal Wilsonians and neoconservatives frequently disappear when they are confronted with large-scale human rights violations abroad that involve mass atrocities, war crimes, or ethnic cleansing. In such circumstances, liberal and neoconservative humanitarian hawks can be expected to agree that unless IO approval is readily available with few strings attached, the short-term costs of forging a multilateral consensus in terms of reduced US policy flexibility will outweigh any longer-term benefits.

First, from a moral standpoint, the interventionist hawks are likely to view military action to relieve the suffering as legitimate, regardless of multilateral approval. Indeed, prominent liberal theorists of humanitarian intervention note that "morality ... is not a bar to unilateral action." ${ }^{29}$ Second, the interventionists are likely to focus primarily on the anticipated payoffs of swift military action and downplay attendant risks and (long-term) operational costs. As former secretary of defense Robert Gates notes, civilian policymakers "considering military intervention ... [at first] virtually never consider the cost." 30 That presumably makes the burden-sharing benefits of IO approval less appealing in their eyes. Finally, in terms of generating and sustaining US domestic support for intervention, hawkish policymakers generally tend to emphasize the importance of decisive leadership and bold initiatives rather than multilateral approval. ${ }^{31}$

${ }^{27}$ See Robert DiPrizio, Armed Humanitarians: US Interventions from Northern Iraq to Kosovo (Baltimore: Johns Hopkins University Press, 2002). For a more critical perspective, see also Tony Smith, America's Mission: The United States and the Worldwide Struggle for Democracy, exp. ed. (Princeton, NJ: Princeton University Press, 2012).

${ }^{28}$ Michael Joseph Smith, "Liberalism and International Reform," in Traditions of International Ethics, ed. Terry Nardin and David R. Mapel (New York: Cambridge University Press, 1992), 215-18; Stefan Halper and Jonathan Clarke, America Alone: The Neo-Conservatives and the Global Order (New York: Cambridge University Press, 2004).

${ }^{29}$ Michael Walzer, Just and Unjust Wars (New York: Basic Books, 1977), 107. See also Fernando Tesón, "The moral basis of humanitarian intervention revisited," in The Ethics of Armed Humanitarian Intervention, ed. Don E. Scheid (New York: Cambridge University Press, 2014).

${ }^{30}$ Gates, Duty, 519. See also Stephen Wertheim, "A Solution from Hell: The United States and the Rise of Humanitarian Interventionism," Journal of Genocide Research 12, nos. 3-4 (December 2010): 149-72; Aaron Rapport, "The Long and Short of It: Cognitive Constraints on Leaders' Assessments of 'Postwar' Iraq," International Security 37, no. 3 (Winter 2012): 133-71.

${ }^{31}$ Barry Blechman and Tamara Cofman Wittes, "Defining Moment: The Threat and Use of Force in American Foreign Policy," in The New American Interventionism, ed. Demetrios P. Caralay (New York: Columbia University Press, 1999), 10; Eliot Cohen, Supreme Command: Soldiers, Statesmen, and Leadership in Wartime (New York: Penguin, 2002), 229. 
Partially because of their steadfast commitment to their cause, the humanitarian hawks tend to be very influential in related policy debates. Arguments in favor of humanitarian intervention also mesh well with America's sense of exceptionalism and unique moral responsibility, which can be expected to further empower the hawks. ${ }^{32}$ Other, more dovish civilian policymakers are usually more concerned about the operational commitment, and consequently they may view the longer-term burden-sharing benefits of securing IO approval as outweighing short-term freedom-of-action costs. However, in the face of a worsening humanitarian situation, the hawks are likely to be able to draw effectively on common morality, shocking imagery, and historical analogies (e.g., the Holocaust or the more recent genocide in Rwanda) to push the United States toward military action. Furthermore, dovish civilian officials may lack the technical expertise to credibly challenge the hawks' feasibility studies and related optimistic assessments about the risks and likely costs of intervention. That is where the American military, with its consistent skepticism about humanitarian intervention, its acknowledged professional expertise, and its high standing in American society, plays a central and hitherto underappreciated role in steering US policy toward multilateralism.

\section{The Senior Officers' Skepticism about Humanitarian Intervention}

Top-level generals and admirals, led by the JCS chairman and vice-chairman, are consistently among the most reluctant doves in US policy debates about humanitarian intervention. They worry more than most civilian officials about operational costs and potential pitfalls down the road. The military's dovish attitude appears to be the result of a combination of ideological preferences, organizational interests, and lessons learned from history.

Samuel Huntington famously noted that military leaders tend to be conservative political realists in foreign affairs. ${ }^{33}$ That insight has been confirmed with regard to the United States by survey research carried out under the auspices of the Triangle Institute for Security Studies (TISS). ${ }^{34}$ As conservative realists, America's military officers usually conceive of national security in terms of traditional realpolitik goals (control of territory, maintenance of geostrategic access and position, and defense of major allies) and are more skeptical of humanitarian and other human rights-driven policies than most civilian leaders-especially those without military experience. ${ }^{35}$ According

\footnotetext{
${ }^{32}$ See Stanley Hoffmann, "American Exceptionalism: The New Version," in American Exceptionalism and Human Rights, ed. Michael Ignatieff (Princeton, NJ: Princeton University Press, 2005).

${ }^{33}$ Huntington, Soldier and the State, 59-65.

${ }^{34}$ Holsti, "Of Chasms and Convergences," 32-34; Szayna et al., Civil-Military Gap, 86.

35 TISS data indicates that 34 percent of civilian leaders with no military experience view "promoting and defending human rights in other countries" as a "very important" US policy goal, while only 13
} 
to TISS data, less than five percent of uniformed leaders view the use of force "to address humanitarian needs abroad" as a "very important" role for the US military, compared to almost twenty percent of non-veteran civilian leaders who view that same goal as "very important." 36 Evidence from other sources also indicates that members of the armed services are generally suspicious of claims about American exceptionalism and significantly less likely than non-veteran civilians to view armed intervention as a viable means of changing the domestic politics of foreign countries. ${ }^{37}$

Parochial organizational interests further magnify the military's reluctance to intervene for humanitarian purposes abroad. The senior uniformed officers who participate in policy debates about armed intervention rise to their position through the ranks of their services; consequently, they tend to be more parochial in outlook than civilian appointees who may join an administration from the private sector or civil society. ${ }^{38}$ As parochial career officials, the generals and admirals want to preserve the health, vitality, and social prestige of their organization. They worry that if the United States intervenes out of a momentary urge to "do something" without a national consensus that important American interests are at stake, it will be difficult to maintain domestic support for the mission, with potentially high long-term costs for the services and their troops. As General David Petraeus notes, "It is, after all, the senior military's institutions-the services to which the officers have devoted their lives - that have the most to risk in foreign intervention." 39

Finally, the senior officers' views on armed intervention and their concerns about maintaining domestic support for potentially open-ended deployments reflect the traumatic experience of America's war in Vietnam. As that war became protracted, Congress eventually cut off funding for all American troops after a set deadline, forcing a humiliating withdrawal. ${ }^{40}$ The military's "lessons of Vietnam" are concisely summarized in what has

percent of active-duty military officers agree. See, for example, Holsti, "Of Chasms and Convergences," 35; Feaver and Gelpi, Choosing Your Battles, 37-38.

${ }^{36}$ The views of civilian leaders with military experience are closer to those of active-duty military officers: only about 10 percent of them rate the goal as "very important." See, for example, Holsti, "Of Chasms and Convergences," 46; Feaver and Gelpi, Choosing Your Battles, 46-47.

${ }^{37}$ Pew Social and Democratic Trends, War and Sacrifice in the Post-9/11 Era: The Military-Civilian Gap (Washington, DC: Pew Research Center, 5 October 2011), 22-26. For evidence that policymakers without prior combat experience tend to be more hawkish, see also Michael C. Horowitz and Allan C. Stam, "How Prior Military Experience Influences the Future Militarized Behavior of Leaders," International Organization 68, no. 3 (Summer 2014): 527-59.

${ }^{38}$ Betts, Soldiers, Statesmen, and Cold War Crises, 40; Szayna et al., Civil-Military Gap, 68.

${ }^{39}$ Petraeus, "Military Influence," 498. For an alternative view, which traces the cautious nature of US military officers back to the American tradition of strong civilian control and the related ability of civilian leaders to punish officers for botched military interventions, see Tood S. Sechser, "Are Soldiers Less War-Prone than Statesmen?" Journal of Conflict Resolution 48, no. 5 (October 2004): 746-74.

${ }^{40}$ Richard Grimmett, "Congressional Use of Funding Cutoffs Since 1970 Involving US Military Forces and Overseas Deployments," CRS Report for Congress (Washington, DC: Congressional Research Service, 2007), 2-3. 
become known as the Weinberger-Powell Doctrine on the use of American force. The doctrine, which continues to enjoy widespread support among senior military officers, holds among other things that the United States should intervene only as a last resort, when "vital" American interests are threatened, when there is "reasonable assurance" that Congress and the American public will be supportive, and when policymakers have identified a clear exit strategy. ${ }^{41}$ The most consistently cautious about armed intervention and humanitarian intervention in particular have been generals in the US Army and Marine Corps, given that their services typically bear the greatest burden in terms of ground combat, logistics, and long-term stabilization. ${ }^{42}$

\section{Demand for Burden Sharing and Exit Strategies}

America's top-level military officers can be expected to acquiesce to a proposed humanitarian intervention, if they believe that the risk to US forces will be minimized (e.g., by relying exclusively on airpower during the active combat phase) and that US forces will not carry the main burden-particularly for "postcombat" stabilization missions where success is notoriously elusive. The senior officers' preference for burden sharing on peacekeeping and stabilization follows naturally from their concerns about the operational costs of intervention and related worries about US domestic support. General John Abizaid, formerly director of the Joint Staff and commander of Central Command, summarizes the military's view as follows: "American troops are best employed when decisive military force needs to be applied, but as combat operations are over and you move toward stabilization, the force structure should be increasingly international." ${ }^{43}$ In line with that, the Pentagon's 2012 strategic guidance document and the 2014 Quadrennial Defense Review, both of which reflect the military's concerns, put strong emphasis on international burden sharing for peacekeeping and stability operations overseas. ${ }^{44}$

Survey research further indicates that a majority of US military officers believe it is appropriate for the uniformed leaders to "insist" on the need for an exit strategy vis-à-vis civilian authorities. ${ }^{45}$ General Colin Powell, with whom the notion of an exit strategy is now commonly associated, interprets

\footnotetext{
${ }^{41}$ Walter LaFeber, "The Rise and Fall of Colin Powell and the Powell Doctrine," Political Science Quarterly 124, no. 10 (Spring 2009): 71-93. For evidence of the doctrine's continuing popularity among senior military officers, see Feaver and Gelpi, Choosing Your Battles, 50-53; Szayna et al., Civil-Military Gap, 141-45.

42 Betts, Soldiers, Statesmen, and Cold War Crises, 116-22; Petraeus, "Military Influence," 497.

${ }^{43}$ Gen. John P. Abizaid (Joint Staff director, 2001-2, and CENTCOM Commander, 2003-7), interview by author, 20 January 2011.

${ }^{44}$ US Department of Defense, Sustaining US Global Leadership: Priorities for the 21st Century (Washington, DC, 5 January 2012); US Department of Defense, Quadrennial Defense Review 2014 (Washington, DC, 4 March 2014).

${ }^{45}$ Holsti, "Of Chasms and Convergences," 87.
} 
it as meaning that before American troops are committed abroad "you better think through how it ends and what happens at the end." 46 Particularly in the context of humanitarian intervention, the US exit strategy has increasingly consisted in handing off longer-term peacekeeping and stabilization tasks to follow-on UN or NATO missions, with the majority of troops contributed by other international partners. A recent US Army field manual accordingly notes that officers planning a humanitarian intervention should aim to "accomplish transfer of authority [to follow-on multilateral missions] as early as possible. The timing of the transfer [ought to be] part of the initial negotiations." ${ }^{47}$

America's military leaders clearly understand that IO involvement can help legitimate the use of force and facilitate burden sharing, as evidenced by the fact that close to eighty percent of military officers emphasize the need to enlist the cooperation of the UN in settling international disputes. ${ }^{48}$ That said, top-level generals and admirals are unlikely to recommend explicitly that the United States seek approval from the UNSC or NAC before intervening. The standard view among senior military officers, as General Powell explains, is that whether the United States seeks IO approval "is a political matter, and it is up to the political leadership to ultimately decide it." 49 What the uniformed leaders are likely to request is some reassurance that large numbers of American troops will not be deployed in costly peacekeeping and stabilization missions for the indefinite future, particularly when they believe that no important US national interests are involved. ${ }^{50}$

\section{IO APPROVAL TO REASSURE AND MOLLIFY THE MILITARY}

Senior military officers are not the only US national security leaders who can be expected to emphasize the operational costs and potential pitfalls of humanitarian intervention. Risk-averse doves among the civilian leadership, especially war veterans and others with significant ties to the armed services, might express similar concerns. Indeed, civilian Pentagon officials usually underscore the military's concerns in the interagency debate. However, the uniformed leaders, because of their acknowledged professional expertise and preeminent role in the planning and execution of military operations, have a unique ability to effectively highlight the risks and likely operational

\footnotetext{
${ }^{46}$ Gen. Colin L. Powell (US national security adviser, 1987-89; JCS chairman, 1989-93; and US secretary of state, 2001-5), interview by author, 2 February 2011.

${ }^{47}$ US Department of the Army, "The Army in Multinational Operations," FM 3-16 (8 April 2014), chap. $5, \S 14$.

${ }^{48}$ Holsti, "Of Chasms and Convergences," 36-38. See also Szayna et al., Civil-Military Gap, 101-3.

${ }^{49}$ Powell, interview; confirmed by Abizaid, interview.

${ }^{50}$ At a lower level, senior military planners on the Joint Staff and at the regional combatant commands (especially the J-5 directors for strategic plans and policy) might go further, de facto advising that the United States intervene only with IO approval when they explicitly foresee it in their recommended options for the president.
} 
costs of intervention. The military's high standing in American society further magnifies the senior officers' leverage.

\section{The Senior Officers' Leverage}

Senior military officers can rely on their professional expertise and related informational advantage to portray some solutions as impractical. If the generals disagree with a specific use-of-force option, they can artificially inflate the required troop numbers and anticipated casualties to make it appear politically unfeasible. As former national security adviser Anthony Lake explains, when the "senior military guys are saying, 'This mission can't be done,' it's hard to say, 'Listen, you professionals, here's an amateur's view of how and why it can be done." 51 The generals' informational advantage has probably never been greater, given that the number of civilian government officials with military experience has been steadily decreasing. ${ }^{52}$

But top-level military leaders can also act as more straightforwardly political players. At a time of generally declining popular support for public institutions in the United States, including Congress and the presidency, Americans continue to express high levels of confidence in the armed services. ${ }^{53}$ Consequently, by opposing a particular policy in private and even just hinting at the possibility that they might openly voice their disagreements with the civilian leadership, the generals can wield significant influence over military intervention decision making-especially when the policy is already domestically controversial. ${ }^{54}$

To further increase their leverage, the uniformed leaders might surreptitiously leak their reservations to the media, openly express their concerns about the risks and operational costs of intervention during press conferences and public congressional hearings, and even threaten their resignation as a last resort. ${ }^{55}$ So long as the civilian principals are divided over how to proceed (and particularly as long as the secretary of defense sides with the uniformed leaders), a JCS chairman or regional combatant commander who openly expresses the military's concerns faces a low probability of being

\footnotetext{
51 Quoted in Samantha Power, A Problem from Hell: America and the Age of Genocide, 3rd ed. (New York: Harper Perennial, 2003), 316.

52 See Mark Thompson, "The other 1\%," Time, 21 November 2011, 34-39. On the military's informational advantage and its implications, see also Peter D. Feaver, Armed Servants: Agency, Oversight, and Civil-Military Relations (Cambridge, MA: Harvard University Press, 2003), 68-70.

53 According to a 2014 Gallup poll, 74 percent of Americans have confidence in the military, 29\% percent in the presidency, and a record-low 7 percent in Congress. Gallup, "Confidence in Institutions," public opinion poll, 5-8 June 2014.

${ }^{54}$ Risa Brooks, "Militaries and Political Activity in Democracies," in American Civil-Military Relations, ed. Suzanne C. Nielsen and Don M. Snider (Baltimore: Johns Hopkins University Press, 2009), 232-33; Bacevich, "Elusive Bargain," 247-49.

55 Brooks, "Militaries and Political Activity," 219-20; Betts, Soldiers, Statesmen, and Cold War Crises, $43-45$.
} 
punished by the president for speaking out. ${ }^{56}$ Even if the senior generals do not aim to undermine administration policy, their public expressions of concern in response to questions from journalists or members of Congress are likely to have that effect in practice: recent survey research indicates that perceived military opposition to proposed uses of force has a significant negative effect on US public support for intervention, reducing that support by seven percentage points on average. ${ }^{57}$

In short, as long as the top-ranking uniformed leaders remain opposed and civilian authorities are themselves divided over whether to intervene (which is likely for humanitarian crises that do not clearly threaten US national security), "the military [has the ability to] exercise a veto over the use of American force. ${ }^{58}$ Under such circumstances, the civilian interventionists need to be able to reassure the military establishment, or at least demonstrate that the military's concerns have been adequately addressed, in order to keep the use of force on the agenda and gradually shift the bureaucratic balance of power in favor of intervention.

\section{Overcoming the Generals' Veto}

Confronted with a military veto of a proposed humanitarian intervention, hawkish civilian policymakers face an uphill bureaucratic battle. At a minimum, they need to get the generals to no longer explicitly oppose the intervention. To that end, the civilian hawks, who are likely to have initially focused primarily on the expected payoffs of their preferred course of action, need to grapple with operational details to a much greater degree. "The military are very good at making the civilian leadership think all the way down the line in the interagency discussions and helping them understand the implications of their actions," explains Donald Kerrick, a former deputy US national security adviser. ${ }^{59}$ In the course of the resulting back-and-forth debate between senior military officers and civilian leaders, even the most hawkish civilians are likely to have to acknowledge that a resource-intensive and potentially open-ended troop commitment may be necessary to achieve US strategic objectives and that maintaining congressional support will be difficult in the absence of sustained burden sharing.

Ultimately, to win the bureaucratic battle, the civilian interventionists need to be able to make a persuasive case that the use of force is a last

\footnotetext{
${ }^{56}$ Avant, "Are the Reluctant Warriors Out of Control?" esp. 56-59; Feaver, Armed Servants, 87-90.

${ }^{57}$ Jim Golby, Kyle Dropp, and Peter Feaver, "Listening to the Generals: How Military Advice Affects Public Support for the Use of Force" (Washington, DC: Center for a New American Security, April 2013).

58 Richard H. Kohn, "The Erosion of Civilian Control of the Military," Naval War College Review 55, no. 3 (Summer 2002): 15. See also Avant, "Reluctant Warriors," 58-59; Desch, Civilian Control of the Military, 22-33; Bacevich, "Elusive Bargain," 248-49.

${ }^{59}$ Lt. Gen. Donald L. Kerrick (NSC director of European affairs, 1994-95, and deputy assistant to the president for national security affairs, 1997-99), interview by author, 22 March 2010.
} 
resort, the objectives of military action are clearly and narrowly defined, international partners support the policy and are willing to shoulder a significant portion of the longer-term burden, and a viable exit strategy exists for American forces. As a result, even the most determined humanitarian hawks, who at first may have wanted to bypass the United Nations and NATO to maximize US freedom of action, can be expected to update their costbenefit analysis vis-à-vis multilateralism. The hawks will reluctantly come to agree with the doves that delaying US military action, accepting potentially cumbersome multilateral coordination, and even offering side-payments to recalcitrant IO member states may be worthwhile and perhaps necessary in order to secure UN or NATO approval and reassure the generals about longer-term burden sharing. Securing IO approval by itself may be insufficient to mollify a reluctant military leadership; but such approval, combined with a narrowly defined mission and concrete pledges of operational support from international partners, can be expected to reduce the military's opposition to a point where the president may feel comfortable taking a final decision to intervene.

The uniformed leaders are likely to play a particularly salient role in multilateralizing coercive humanitarian missions that aim to resolve a humanitarian crisis at its roots by forcibly changing the domestic authority structure of the target state. Such coercive missions are in tension with the principle of noninterference in states' domestic affairs, as enshrined in Article 2 of the UN Charter. Consequently, there are good reasons to expect that emerging powers such as China, Russia, India, and Brazil (who are attached to traditionalist interpretations of state sovereignty), as well as America's closest European allies (whose domestic audiences attach great value to compliance with UN Charter law), will be reluctant to offer their affirmative vote at the UNSC or NAC. ${ }^{60}$ As the difficulties of securing multilateral approval become apparent, civilian policymakers in Washington who strongly advocate the use of force for internal political change may at first be especially inclined to bypass the UN and NATO. Such coercive humanitarian missions, however, are also the types of intervention about which the American military has the greatest reservations, given the likelihood of open-ended commitments with dwindling US domestic support. The military's role then becomes central in multilateralizing those particular types of interventions: the generals' fear of costly quagmires and their threat to veto such interventions altogether can motivate even heavyweight humanitarian hawks to make the extra effort needed to secure multilateral approval.

\footnotetext{
${ }^{60}$ On emerging powers' traditionalist interpretation of sovereignty, see Oliver Stuenkel, "The BRICS and the Future of R2P," Global Responsibility to Protect 6, no. 1 (January 2014): 3-28. On the Europeans' attachment to UN Charter law, see Joachim Krause, "Multilateralism: Behind European Views," Washington Quarterly 27, no. 2 (2004): 43-59.
} 
Securing UN or NATO approval is usually less challenging for more limited, less intrusive humanitarian operations aimed at protecting populations under threat of attack and/or facilitating the delivery of emergency assistance. In those latter cases, US policymakers can be expected to readily agree that the limited international negotiations required to secure IO approval are worthwhile, and consequently the military's role in persuading civilian authorities to seek IO approval will be less salient. Summing up, the uniformed leaders' role in steering US humanitarian intervention policy toward the UNSC or NAC is likely to become more central as the intrusiveness of a planned operation increases and securing IO approval accordingly becomes more difficult.

\section{CIVIL-MILITARY BARGAINING ON HAITI AND KOSOVO}

During the debates about US military intervention in Haiti (1993-94) and Kosovo (1998-99), some of the most senior US civilian policymakers persistently advocated a swift use of force aimed at internal political change (restoring an ousted head of state in the first case and enforcing ethnic minority rights in the latter). Other IO member states were hesitant on both occasions to offer their affirmative vote for such intrusive missions. That initially prompted the civilian hawks in Washington to advocate US unilateral intervention. Meanwhile, a risk-averse US military leadership was wary about intervention and outright opposed to proceeding unilaterally. Focusing on the Haiti and Kosovo cases is therefore useful for illustrating and probing the plausibility of the argument that the military leaders constitute the ultimate bulwark against US unilateral humanitarian intervention. Other postCold War humanitarian interventions, such as Somalia in 1992 and Liberia in 2003, enjoyed significant international support a priori. Those were (at least initially) limited missions aimed at facilitating the delivery of emergency humanitarian assistance; securing IO approval was not difficult; and no senior US official opposed a multilateral course of action. Consequently, in those cases, the military's role in multilateralizing US policy was probably less central. ${ }^{61}$

Investigating US decision making on Haiti and Kosovo is also useful for other reasons. The Haiti and Kosovo interventions were backed by different

\footnotetext{
${ }^{61}$ On Somalia, see Nora Bensahel, "Humanitarian Relief and Nation Building in Somalia," in The United States and Coercive Diplomacy, ed. Robert Art and Patrick Cronin (Washington, DC: US Institute of Peace, 2003), 21-56; Nicholas Wheeler, Saving Strangers: Humanitarian Intervention in International Society (Oxford: Oxford University Press, 2000), 184-85. On Liberia, see Richard Stevenson and Christopher Marquis, "Bush Team Faces Widespread Pressure to Act on Liberia," New York Times, 23 July 2003; more generally, Alan J. Kuperman, "A small intervention: Lessons from Liberia 2003," in Naval Peacekeeping and Humanitarian Operations: Stability from the Sea, ed. James J. Wirtz and Jeffrey A. Larsen (New York: Routledge, 2008), chap. 11.
} 
IOs-the United Nations and NATO, respectively-and therefore studying these two cases might elucidate the relative merits of securing approval from one versus the other. Furthermore, the Haiti and Kosovo interventions occurred long enough ago that several former policymakers are now willing to speak candidly about their motivations and concerns at the time. As a result, the US decision-making process can be reconstructed with a higher degree of confidence than would be possible for more recent interventions.

The argument developed in previous pages would be strongly corroborated if key policymakers who were initially willing to bypass relevant IOs acknowledged that the military's veto threat was, indeed, what persuaded them to seek UN or NATO approval. Policymakers, however, tend to downplay the importance of bureaucratic compromises forced upon them by others, presumably because they dislike giving credit to their opponents and instead prefer to emphasize their own leadership and initiative. As research by Etel Solingen shows, in the field of national security, "leaders and state officials have incentives to justify decisions in terms of 'reasons of state' [or] by appealing to norms [rather] than by wielding parochial political considerations." 62 It follows that the role of bureaucratic bargaining in this field is hard to substantiate, and as a result "even partial substantiation ... gains particular significance." 63

Below I present direct evidence from interviews in which several former policymakers acknowledge the importance of securing multilateral backing for mollifying a reluctant military leadership. But the motives that led to the adoption of particular policies can also be established indirectly by carefully tracing the decision-making process. If hawkish civilian policymakers were initially willing to bypass the UNSC and NAC, but the risk-averse generals were able to block US intervention until the civilian leadership secured IO approval as well as more specific burden-sharing commitments, it can be inferred that the generals played an important role in multilateralizing US policy. Information gathered from interviews is not always reliable, as personal memories may be distorted by hindsight. However, if interviewees from different agencies and departments offer similar conclusions and their analyses are compatible with the written record, confidence in the findings increases. For data triangulation, I also rely on declassified documents, some of which have been released pursuant to a Mandatory Declassification Review that I requested from US authorities. ${ }^{64}$

\footnotetext{
${ }^{62}$ Etel Solingen, Nuclear Logics: Contrasting Paths in East Asia and the Middle East (Princeton, NJ: Princeton University Press, 2007), 13, 16.

${ }^{63}$ Ibid., 5.

${ }^{64}$ Documents released pursuant to Mandatory Declassification Review (MDR) Request 2009-0983-M, submitted by author, now available at http://clinton.presidentiallibraries.us/collections/show/36/.
} 
Haiti, 1993-94

In September 1994, twenty thousand US troops intervened in Haiti to put an end to systematic human rights violations and restore to office Jean-Bertrand Aristide, the country's democratically elected president who had been ousted in a military coup three years earlier. During the summer preceding the intervention, the United States made an all-out effort to secure UN approval for forcibly restoring Aristide to office. Former president Bill Clinton recalls that "it took months to build support ... in our hemisphere [and] even longer to win the improbable 12-0 mandate from the UN Security Council." 65 To secure UN approval, the United States accepted a logrolling bargain with Russia: in exchange for Moscow's cooperation at the Security Council on Haiti, Washington agreed to support a Security Council mandate for Russian occupation forces in Georgia. ${ }^{66}$ Furthermore, the United States applied significant pressure on its hesitant international partners, especially in the Western Hemisphere: recently declassified documents show that Washington explicitly linked US economic assistance in the hemisphere to support for its policy on Haiti. ${ }^{67}$ Why were US leaders willing to delay military action and resort to these costly measures to secure UN approval?

\section{The InTERventionists' InITIAL Cost-Benefit ANALysis}

Soon after the Clinton administration took office in early 1993, national security adviser Anthony "Tony" Lake began calling for military intervention in Haiti. As Lawrence Pezzullo, then the US special envoy for Haiti, remembers, "The first meeting I had with Tony Lake at his office [in March 1993], he said that we might have to use military force." ${ }^{68}$ Over the next year, Lake and his deputies, Samuel Berger and Nancy Soderberg, as well as Lawrence Rossin, the Haiti policy director on the NSC staff, became increasingly convinced

\footnotetext{
65 Quoted in Taylor Branch, The Clinton Tapes: Wrestling History with the President (New York: Simon \& Schuster, 2009), 185-86. Brazil and China abstained on the Security Council vote, and the representative of Rwanda, a country ravaged by genocide at the time, was not present, hence the 12-0 outcome. See Malone, Decision-Making in the UN Security Council, 109-10.

${ }^{66}$ James Boone, "US and Russia broker Haiti invasion deal," The Times, 1 August 1994. See also Madeleine Albright, Madam Secretary: A Memoir (New York: Miramax, 2003), 158; Malone, DecisionMaking in the UN Security Council, 107.

${ }^{67}$ National Security Council, "Summary of Conclusions of Meeting of NSC Deputies Committee," 10 May 1994 (document released pursuant to MDR request 2009-0983-M, submitted by author). See also Latin American Intelligence Service, "Another two-step from Washington," Latin American Weekly Report, 23 June 1994.

${ }^{68}$ Lawrence Pezzullo (US special envoy to Haiti, 1993-94), interview by author, 24 June 2009. See also Nancy Soderberg, The Superpower Myth (New York: Wiley, 2005), 46. On the Haiti intervention more generally, see Robert Pastor, "The Delicate Balance between Coercion and Diplomacy: The Case of Haiti, 1994," in The United States and Coercive Diplomacy; Sarah E. Kreps, "The 1994 Haiti Intervention: A Unilateral Operation in Multilateral Clothes," Journal of Strategic Studies 30, no. 3 (2007): 449-74.
} 
that no meaningful progress would be possible in Haiti without military intervention. ${ }^{69}$

The administration's leading interventionists on the NSC staff were at first not especially concerned about the possibility of an open-ended US troop deployment. As Rossin acknowledges, "The idea that we would somehow get stuck there and therefore needed to have an exit strategy before we got in was not something that was part of the discussion until pretty late in the day." ${ }^{70}$ Focusing on the payoffs of military action and anticipating a limited operational commitment, the interventionists did not view international burden sharing, as facilitated by IO approval, as particularly advantageous, let alone essential. "Dealing with Lake and Berger," Rossin explains, "I don't remember that they agonized over whether or not there was international approval for this intervention." $" 1$

Lake confirms that initially he did not view UN approval as essential. He believed that securing UN approval would be difficult, given widespread Latin American opposition to US intervention in the hemisphere. ${ }^{72}$ The national security adviser doubted that the effort would be worthwhile. Once obtained, a UNSC mandate would hardly help to increase US domestic support for intervention because "with a lot of the Congress, having a UN cover is not a good thing," and the burden sharing that it could facilitate would be only marginally beneficial because "Haiti is not Vietnam." ian interventionists anticipated that regardless of UN approval, following the deployment of US troops, Congress and the American public would rally around the flag and support the president. A confidential note written in May 1994 by Dante Caputo, the UN special representative for Haiti, and based on conversations with senior US officials, highlights that key policymakers in Washington expected "that the current opposition of public opinion to an armed intervention will change radically, once it will have taken place."74

By the spring of 1994 senior officials at the State Department increasingly joined the NSC staff in advocating US military intervention. ${ }^{75}$ Secretary of State, Warren Christopher, a World War II veteran, was personally reluctant

\footnotetext{
${ }^{69}$ Ann Devroy and Jeffrey Smith, "Debate Over Risks Split Administration," Washington Post, 25 September 1994.

${ }^{70}$ Lawrence Rossin, (Haiti policy director, NSC staff, 1993-94), interview by author, 25 July 2009; confirmed by Pezzullo, interview.

${ }^{71}$ Rossin, interview.

${ }^{72}$ He says he didn't "expect them [i.e., the Latin Americans], practically under any circumstances, to be in favor of an American intervention in the hemisphere, because of history." Anthony D. Lake (US national security adviser, 1993-97), interview by author, 26 June 2009.

${ }^{73}$ Lake, interview.

${ }^{74}$ Confidential note to the UN secretary-general from special representative of the secretary-general Dante Caputo, 23 May 1994 (leaked and published in the Congressional Record, 29 September 1994). On the expectation of a rally-round-the-flag effect, see also R.W. Apple Jr., "Showdown in Haiti: Preaching to Skeptics," New York Times, 16 September 1994.

${ }^{75}$ Pezzullo, interview. See also Branch, Clinton Tapes, 188.
} 
but mostly stayed on the sidelines of the debate. Meanwhile Strobe Talbott, who became deputy secretary of state in February 1994 and whose influence was magnified by his personal friendship with President Clinton, supported a force-based strategy. Madeleine Albright, then the US ambassador to the United Nations, was an avowed hawk on Haiti, as was James Dobbins, who became the State Department's new Haiti policy coordinator in April. ${ }^{76}$ The most hawkish State Department officials at first explicitly opposed the idea of seeking a UN mandate. Dobbins, in particular, insisted that the United States should not even try, because the effort would be exceedingly costly, time consuming, and unlikely to succeed. ${ }^{77}$ Talbott was not opposed to seeking UN approval in principle, but he, too, downplayed its likely payoffs; similar to Lake, he doubted that a Security Council mandate would help increase US domestic support for intervention, "because a lot of our domestic critics weren't very crazy about the UN, either."78

\section{Military SKePticism AND THE Lessons OF SOMALia}

If President Clinton nevertheless remained unwilling to authorize US intervention until the late summer of 1994, when UN approval and a credible exit strategy had become available, that appears to have been to a significant degree the result of strong intramural resistance from the Pentagon and the US military establishment in particular. America's top-level generals and admirals disputed that important US national interests were at stake in Haiti; they were skeptical about using force to restore democracy and protect human rights; and they persistently warned that the civilian interventionists' expectation of a short in-and-out mission was unrealistic. ${ }^{79}$ Admiral William Owens, the JCS vice chairman at the time, recalls attending several NSC meetings in which, as he puts it, "the idealism of senior administration officials was running rampant" and the military was cautioning against the view that "everything was going to be rosy after [the United States] had gotten in and reestablished the leader." 80

The military's concerns about intervening in Haiti were exacerbated following the killing of eighteen Army Rangers deployed on a humanitarian mission in Mogadishu, Somalia, on 3 October 1993. ${ }^{81}$ The Somalia intervention had initially been conceived as a short in-and-out mission in late

\footnotetext{
${ }^{76}$ Devroy and Smith, "Debate Over Risks Split Administration." See also Albright, Madam Secretary, 157.

${ }^{77}$ James Dobbins (special Haiti coordinator, US Department of State, 1994-95), interview by author, 9 July 2009.

${ }^{78}$ Strobe Talbott (deputy US secretary of state, 1994-2001), interview by author, 9 July 2009.

${ }^{79}$ John Christiansen (Haiti task group director, US Department of Defense, 1993-97), interview by author, 15 July 2009. See also Albright, Madam Secretary, 157; David Halberstam, War in a Time of Peace: Bush, Clinton, and the Generals (New York: Touchstone 2001), 269-79.

${ }^{80}$ Adm. William Owens (JCS vice chairman, 1994-96), interview by author, 27 January 2011.

${ }^{81}$ Avant, "Reluctant Warriors," 72-73; Albright, Madam Secretary, 156-57.
} 
1992: American forces would limit themselves to opening up the food supply routes blocked by rebel militias, while longer-term nation building would be left to a UN mission with only minimal US participation. ${ }^{82}$ However, in 1993 the Somalia intervention ended in a quagmire after President Clinton, far from withdrawing American troops, acquiesced to a request from the UN secretary-general to change the mission to peace enforcement. Escalating clashes with Somali militias culminated in the 3 October killing, prompting Congress to enforce a withdrawal of all American troops by cutting off funding. ${ }^{83}$

America's military leadership learned several lessons from the Somalia experience. First, US objectives in humanitarian operations have to be limited and must be clearly defined from the outset. Second, before deploying American troops in humanitarian missions overseas, US policymakers need to obtain a firm commitment from the UN or regional IOs as well as from potential troop contributors that there will be a relatively quick handoff to a follow-on multilateral mission led by other countries. Finally, the transition to follow-on multilateral missions has to be planned in much greater detail. Significantly, however, although civilian administration officials used the UN as a scapegoat for the failure in Somalia, the US military blamed the haphazard strategy of the civilian leadership in Washington and remained convinced that the UN-handoff idea could represent a useful model for the future. ${ }^{84}$

As a result, when President Clinton requested the development of contingency plans for US intervention in Haiti in late 1993, the Joint Staff, under the coordination of Lieutenant-General Wesley Clark, then the J-5 director for strategic plans and policy, developed a matrix of specific tasks to be accomplished by American forces before longer-term stabilization could be handed off to the United Nations. ${ }^{85}$ The US Atlantic Command (USACOM) delivered a draft operations plan (code named OPLAN 2370) by February 1994. The plan envisaged a twenty-four day US military operation in Haiti,

\footnotetext{
${ }^{82}$ Adm. David Jeremiah (JCS vice chairman, 1990-93), interview by author, 28 January 2011. For a useful discussion, see also Herman J. Cohen, assistant secretary of state for African affairs, 1989-93, Intervening in Africa (New York: St. Martin's Press, 2000), 210-14.

${ }^{83}$ Bensahel, "Humanitarian Relief," 35-45. See also Grimmett, "Congressional Use of Funding Cutoffs," 3 .

${ }^{84}$ Gen. Walter Kross (Joint Staff director, 1994-96); Adm. Frank L. Bowman (director for politicalmilitary affairs, Joint Staff, 1992-94); Col. William J. Flavin (assistant to deputy chief of operations, Army Staff, 1992-94, and director of doctrine, concepts, education, and training, US Army Peacekeeping and Stability Operations Institute, 1999-2013), interviews by author, 18 January, 11 February, and 27 April 2011, respectively.

${ }^{85}$ Flavin, interview. See also John R. Ballard, Upholding Democracy: The United States Military Campaign in Haiti, 1994-1997 (Westport, CT: Praeger, 1998), esp. 62-66.
} 
after which longer-term stabilization tasks would be handed off to a multilateral (preferably UN) force. ${ }^{86}$ The final operations plan approved by the Joint Staff on 20 May 1994 explicitly foresaw that after a forced entry by the 82nd Airborne Division and a short US-led stabilization effort, "US forces will be replaced as UNMIH [UN Mission in Haiti] forces arrive." ${ }^{87}$

\section{Moldifying a Reluctant Military Leadership}

According to Frank Wisner, who at the time was undersecretary of defense for policy, there was "practically a doctrinal assumption" among the military leadership that the mission in Haiti had to be internationalized from the beginning ${ }^{88}$ Admiral Owens says that, although the Joint Chiefs did not explicitly request UN approval, they insisted that following the initial US intervention, "there needed to be a United Nations force that would come in and be committed, with the size and texture to do this for the long term, because it wasn't going to get fixed in the short term." ${ }^{89}$ Military planners on the Joint Staff were more explicit in recommending that the administration secure UN approval ahead of intervention: whenever they briefed the president and NSC, remembers General Walter Kross, who directed the Joint Staff at the time, "the UN sanction upfront would certainly be in the recommended option ... [because] it was really a central element of our exit strategy." 90

Process tracing of the policy's development in the spring and summer of 1994 further clarifies the military's role. During an NSC principals' meeting on 7 May, Lake suggested that it would be "useful" to take a decision on the shift toward a force-based strategy. Thereupon, JCS chairman General John Shalikashvili presented the latest US invasion plan, but he insisted that the military, on its own, could not "deliver ... a plan on how to get out." ${ }^{\text {91 }}$ In previous days, high-ranking military officers had emphasized their concerns about the risk of an open-ended US commitment in interviews with the press, publicly worrying about the absence of UN approval. ${ }^{92}$ That was a clear signal that the senior officers would remain opposed, until the administration offered them credible assurances about multilateral burden

\footnotetext{
${ }^{86}$ Walter E. Kretchik, Robert F. Baumann, and John T. Fishel, Invasion, Intervention, "Intervasion": A Concise History of the U.S. Army in Operation Uphold Democracy (Fort Leavenworth, KS: US Army Command and General Staff College Press, 1998), 48-49.

${ }^{87}$ CINCUSACOM message 131358Z, "Operation Maintain Democracy," 20 May 1994 (on file with author). See also Ronald H. Cole, "Grenada, Panama, and Haiti: Joint Operational Reform," Joint Forces Quarterly 20 (Autumn/Winter 1998-99): 63.

${ }^{88}$ Frank Wisner (undersecretary of defense for policy, 1993-94), interview by author, 16 July 2009.

89 Owens, interview; confirmed by Christiansen, interview.

${ }^{90}$ Kross, interview.

${ }^{91}$ Quoted in Soderberg, Superpower Myth, 49.

92 Barton Gellman and Ruth Marcus, "US Boosts Pressure On Haitians: Use of Force Not Ruled Out, President Declares,” Washington Post, 4 May 1994.
} 
sharing and the availability of an exit strategy-preferably by securing a UN mandate that also foresaw the establishment of a follow-on UN mission within a clearly defined timeframe. ${ }^{93}$

By June 1994 senior military planners at USACOM publicly announced that they "assumed" any military intervention in Haiti would be conducted under a UN mandate. ${ }^{94}$ Also in June, John Deutch, the deputy secretary of defense, invited Strobe Talbott, his equal in rank from the State Department, and James Steinberg, the State Department's head of policy planning, to several informal conversations with the JCS and other high-ranking military officers. Over the following weeks, Talbott in particular, who had for several months been a staunch advocate of intervention, became much more aware of what the military planners viewed as the operation's principal risks. ${ }^{95}$ Lake himself reluctantly acknowledges that it was important to mollify the uniformed leaders and address their principal concerns in order to build up intra-administration support for intervention: "Defining a mission that had an end point was something that it was certainly necessary to work on vis-à-vis the Pentagon."96

From the late spring of 1994 onward, remembers Nancy Soderberg, who then worked under Lake on the NSC staff, the interventionists' strategy to mollify the military and their civilian allies at the Pentagon aimed to "build the case that the intervention was going to be limited and targeted." 97 The centerpiece of this strategy involved securing UNSC approval for the use of force, combined with a UN commitment to establish a follow-on peacekeeping mission led by other countries. SC Resolution 940, adopted on 31 July 1994 did precisely that: it authorized the use of force in Haiti and committed the Security Council to establishing a follow-on UN mission that would "assume the full range of its functions" as soon as basic security had been restored.

Talbott has little doubt that the principal reason why the State Department worked hard to obtain a UNSC mandate explicitly foreseeing such a follow-on mission was to reassure the military leaders: "Ourprincipal reason for wanting to do a handoff to the UN as quickly as possible was that our military really wanted it. It really had to do with [JCS chairman] Shalikashvili."98

\footnotetext{
${ }^{93}$ John Christiansen, who at the time chaired the Pentagon's Haiti task group, recalls how the military worried that it would be exceedingly difficult "to get the UN eventually to come in" without an advance UN mandate that also contained explicit guarantees about the establishment of a follow-on UN force: "That was absolutely critical. The Pentagon would have strenuously objected to going into Haiti without having the commitment of a follow-on [UN] force." Christiansen, interview.

${ }_{94}$ Ann Devroy and Barton Gellmann, "Exodus From Haiti Strains US Policy: Military Intervention Considered," Washington Post, 2 July 1994.

95 Devroy and Smith, "Debate Over Risks Split Administration."

${ }^{96}$ Lake, interview.

${ }^{97}$ Nancy Soderberg (deputy assistant to the president for national security affairs 1993-96), interview by author, 29 July 2009.

98 Talbott, interview (emphasis added).
} 
Morton Halperin, another advocate of intervention who played an important role in shaping US policy toward Haiti as a senior member of the NSC staff, confirms that "the deal that was brokered with the UN was very much to get the military to go in, [because] the generals were concerned about how quickly they could get out." 99

Unnamed senior administration officials subsequently confirmed to the Washington Post that "he [Clinton] waited until September to satisfy Pentagon reservations." 100 Obtaining a Security Council mandate that explicitly foresaw a follow-on UN mission was almost certainly necessary but may not have been sufficient to mollify the military. Other elements of the administration's multi-pronged strategy to reassure the JCS included a CIA-led covert operation in the late summer of 1994 aimed at promoting an internal army coup in Haiti, ${ }^{101}$ systematic efforts to bribe the Haitian de facto leaders into exile by offering them financial incentives, ${ }^{102}$ and a last-ditch diplomatic effort led by former US president Jimmy Carter. Ultimately, Carter, wielding the credible threat of a US invasion, persuaded the Haitian rulers to step down voluntarily and consent to the peaceful deployment of American troops. ${ }^{103}$ By late March 1995, with Aristide restored to the presidency and basic stability reestablished, the United States was able to hand off peacekeeping responsibilities to a six-thousand-strong UN mission, which, according to plan, was composed of a majority of non-US troops. One year later, command of the peacekeeping force was turned over to Canada and Washington withdrew all but a handful of US troops. ${ }^{104}$

Kosovo, 1998-99

On 24 March 1999, the United States and thirteen other NATO members launched a coercive air campaign against the Federal Republic of Yugoslavia, aimed at stopping the systematic oppression and mass expulsion of the Kosovar Albanian population. Forging a NATO consensus on the use of force required months of intense transatlantic negotiations. That undermined Washington's coercive leverage while the humanitarian situation in Kosovo continued to deteriorate. Furthermore, even after the NAC approved the use of force and air strikes began, persistent allied disagreements over strategy

\footnotetext{
${ }^{99}$ Morton Halperin (senior director for democracy on the NSC staff, 1994-96), interview by author, 10 March 2010.

100 Quoted in Devroy and Smith, "Debate Over Risks Split Administration."

101 Doyle McManus and Robin Wright, "Covert Action Fails to Oust Haiti's Rulers," Los Angeles Times, 16 September 1994.

102 Elaine Sciolino, "Top US Officials Divided in Debate On Invading Haiti," New York Times, 4 August 1994.

${ }^{103}$ For a detailed account of Carter's mission, see Pastor, "Delicate Balance."

${ }^{104}$ Larry Rohter, "Clinton, in Haiti, Marks the Withdrawal of G.I.'s," New York Times, 1 April 1995; Strobe Talbott, The Great Experiment (New York: Simon \& Schuster, 2008), 302.
} 
and tactics made for an ineffective use of airpower. ${ }^{105}$ Yet without NATO's approval, "it is pretty clear that it [the humanitarian intervention] would not have happened," explains Walter Slocombe, the undersecretary of defense for policy at the time. ${ }^{106}$

\section{Debating US Unilateral Strikes, April-May 1998}

In the spring of 1998, when the deteriorating humanitarian situation in Kosovo became a matter of growing international concern, Secretary of State Madeleine Albright emerged as the leading advocate of military intervention within the US executive branch. As one of her former aides recalls, "Albright believed very early on that the lessons of Bosnia were that [Yugoslav president Slobodan] Milosevic would respond only to the use of force." 107 During the first half of 1998, most of Washington's European allies-including France, Italy, and Germany-were reluctant to countenance military action to enforce ethnic minority rights. ${ }^{108}$ Consequently, on 23 April 1998, Albright and Robert Gelbard, the State Department's hawkish Balkans envoy, made the case for US unilateral strikes to national security adviser Samuel Berger and his deputy, Donald Kerrick. ${ }^{109}$

Albright and Gelbard's specific proposal was that the United States give Milosevic an ultimatum of between three and five days to remove most of his security forces from Kosovo, and, in case of noncompliance, Washington should "use Tomahawk missiles and in the middle of the night destroy the [Yugoslav] ministry of defense and the ministry of interior." 110 Asked about the role of NATO and the European allies, Gelbard concedes, "I am not even sure we ever thought about the other allies at the time." "111 Berger, however, summarily rejected the proposal. "What if that doesn't work?" he retorted. "Do you continue bombing?"112 The president himself, Albright recalls, subsequently made it "very clear that ... we had to work with the allies, that we weren't going to do this unilaterally."113

\footnotetext{
${ }^{105}$ For useful discussions, see Ivo H. Daalder and Michael E. O'Hanlon, Winning Ugly: NATO's War to Save Kosovo (Washington, DC: Brookings Institution Press, 2000), 31-108; Alex Bellamy, Kosovo and International Society (New York: Palgrave Macmillan, 2002), esp. chaps. 4-6.

${ }^{106}$ Walter Slocombe (undersecretary of defense for policy, 1994-2001), interview by author, 9 June 2011.

${ }^{107}$ James Rubin (assistant secretary of state for public affairs, 1997-2000), interview by author, 9 April 2010. See also Bellamy, Kosovo and International Society, 72-73.

108 Albright, Madam Secretary, 380-83; Daalder and O'Hanlon, Winning Ugly, 28-30; Bellamy, Kosovo and International Society, 86-87.

${ }^{109}$ Kerrick, interview. See also Albright, Madam Secretary, 383; Elaine Sciolino and Ethan Bronner, "Crisis in the Balkans: The Road to War," New York Times, 18 April 1999.

${ }^{110}$ Robert Gelbard (US special envoy for the Balkans, 1996-99), interview by author, 22 March 2010.

111 Gelbard, interview.

112 Gelbard, interview. See also Daalder and O'Hanlon, Winning Ugly, 30; Halberstam, War in Time of Peace, 376.

113 Madeleine Albright, interview, Frontline: War in Europe, PBS, February 2000.
} 
Berger's and the president's skepticism about unilateral airstrikes appears to have been influenced to a considerable degree by their frequent interactions with representatives of the JCS. "We used to talk to Sandy [Berger] a lot," recalls General David Weisman, who at the time played a key liaison role between military and civilian leaders as the deputy head of strategic planning on the Joint Staff. "Bob Gelbard," he adds, "had no idea about how to deploy military force." 114

\section{The Military's Concerns}

The Joint Chiefs, led by General Henry "Hugh" Shelton and his deputy, General Joseph Ralston, doubted that airpower alone could persuade Milosevic to accede to Washington's demands, and they feared it might put the United States on a slippery slope toward a full-scale ground invasion. "People would say, 'OK just the threat of airstrikes will work,'” General Ralston recalls. "Well, then we'd ask, what if it doesn't? 'OK,' they replied, 'then if you drop one or two bombs, it will solve the problem.' Well, we continued, what if it doesn't? Ultimately, you'd have to be prepared to introduce ground forces, or do whatever was needed." 115

The JCS further worried that even if airpower persuaded Milosevic to capitulate, ultimate success in Kosovo would require an open-ended international military commitment to maintain security for the long term. ${ }^{116}$ Colonel Gregory Kaufmann, then a senior official on the Pentagon's Balkans task force, explains that, from early on, the military planners "were very much looking at SFOR [i.e., the international stabilization force in Bosnia]. Our thought was that we would have to deploy a similar kind of force in Kosovo." 117 In the intramural debates, the uniformed leaders expressed concerns that, with the Bosnia mission still ongoing, Congress might not support another large-scale and protracted US troop deployment to the Balkans, which made it imperative in their eyes that the stabilization burden in Kosovo

${ }^{114}$ Lt. Gen. David Weisman (Joint Staff vice director for strategic plans and policy, 1995-98; US military representative, NATO Military Committee, October 1998-June 2001), interview by author, 16 February 2011.

115 Gen. Joseph Ralston (JCS vice chairman, 1996-2000), interview by author, 17 March 2009. See also Wesley K. Clark, Waging Modern War: Bosnia, Kosovo, and the Future of Conflict (New York: Public Affairs, 2001), 137, 165; Halberstam, War in Time of Peace, 377, 411-16.

116 The only high-ranking military officer who sided with the civilian hawks on this occasion and at first downplayed the likely operational costs was Gen. Wesley Clark, the commander of US and allied troops in Europe. However, the JCS became very irritated at Clark's behavior, and for most of 1998, they quite effectively curtailed Clark's access to the president and the NSC. See Halberstam, War in Time of Peace, 388, 396; Clark, Waging Modern War, 109, 127.

${ }^{117}$ Col. Gregory Kaufmann (chief of staff, 1997-98, and director, 1999-2000, Balkans task force, Office of the Secretary of Defense, 1999-2000), interview by author, 10 March 2010. See also Clark, Waging Modern War, 137, 165, 307. 
be shifted as much as possible to the European allies. ${ }^{118}$ As General Ralston recalls, "The Congress was pretty skeptical about involvement in the Balkans and in Kosovo. The military didn't want to find themselves in a situation where we get started in this and then suddenly the Congress says, 'Well, wait a minute, we're not going to support that.' Because then you don't have a way to succeed." 119 Former advocates of intervention from the State Department concede that, at first, they didn't think a large-scale troop deployment would be needed to maintain stability in Kosovo; consequently, compared to their Pentagon colleagues, they were less concerned about congressional support. $^{120}$

On Kosovo, the generals for the most part expressed their concerns privately in the intramural debates, but they clearly signaled to the civilian leadership that they might speak out in public unless their views were taken seriously. ${ }^{121}$ Berger and Clinton understood that overt opposition from the military could have disastrous implications in terms of public and congressional support for the administration's Kosovo policy. ${ }^{122}$ The civilian advocates of intervention therefore had to mollify the military by answering its concerns. That required, first of all, that the civilian interventionists more systematically consider the goals, likely implications, and potential downsides of armed intervention. James Rubin, one of Albright's closest collaborators at the time, acknowledges that the interventionists at first "didn't want to spend a lot of time thinking about what would happen if it didn't work-that's true." 123 Leon Fuerth, then a senior NSC staffer and influential advocate of US intervention in the Balkans, recognizes the generals' leverage: "You couldn't make it sail unless you could convince the US military that you knew why you were getting into this war," he explains, "and consequently you could define the circumstances under which you would get out."124

\section{MOLLIFying THE GENERALS}

As the humanitarian hawks at the State Department stepped up their advocacy of intervention from the summer of 1998 onward, the Joint Chiefs

118 Gregory Schulte (NSC Balkans policy director, 1998-99), interview by author, 9 March 2010. See also Albright, Madam Secretary, 395; Clark, Waging Modern War, 137-38.

${ }^{119}$ Ralston, interview.

${ }^{120}$ Barbara Larkin (assistant secretary of state for legislative affairs, 1996-99) and James O’Brien (principal deputy director of policy planning at the State Department and special Balkans envoy, 1997-2001), interviews by author, 9 April and 9 March 2010, respectively.

${ }^{121}$ John Hamre (deputy US secretary of defense, 1997-2000), e-mail to author, 17 February 2010.

See also Halberstam, War in Time of Peace, 415.

122 Halberstam, War in a Time of Peace, 375.

123 Rubin, interview.

${ }^{124}$ Leon Fuerth (national security adviser to the vice president, 1993-2000), interview by author, 9 March 2010. 
demanded assurances that following US-led airstrikes, Washington's European allies would take the lead on Kosovo's long-term stabilization. "The US military was very anxious that we not have the main burden-in fact, we wanted to have as little of the burden as we could possibly have," recalls a former senior Pentagon official. ${ }^{125}$ In the fall of 1998, Secretary of Defense William Cohen publicly backed the JCS and set a red line by demanding that any stabilization force for Kosovo should be "largely, if not wholly, European in nature, given [that US forces] will be carrying the bulk of the load" in any preceding air campaign. ${ }^{126}$

In top-level policy meetings, the military leaders did not explicitly demand a NATO endorsement for the use of force but nevertheless made their preference in this regard clearly known. Extrapolating from the previous experience in Bosnia, the Joint Chiefs expected that securing NATO's approval for airstrikes and involving the alliance in all aspects of policy planning and implementation would help commit NATO and its principal member states to sustained burden sharing. "If there was going to be a military solution, we wanted to make sure that the allies were on board," recalls General Weisman, the deputy head of strategic planning on the Joint Staff. "We needed the NATO endorsement, and NATO had to take the lead, so that everybody would be involved, not only with the operation, but also with the peace afterwards-in fact, that was the most important part."127

Albright recalls that, given the Pentagon's resistance to armed intervention, "to forge a consensus within my own government [was] not an easy task." 128 The secretary of state and her fellow civilian interventionists thus gradually came to realize that obtaining NATO's endorsement, as well as more specific burden-sharing commitments from the European allies, offered the best prospect of mollifying the reluctant generals. As Albright's former executive assistant explains, "to the extent that the secretary could reject the Pentagon's argument" about the risks and likely costs of intervention, "that certainly helped us in the interagency debate." ${ }^{29}$ Morton Halperin, the State Department's director of policy planning at the time, is more explicit: "We wanted this as a shared burden, and we wanted the US forces to get out as quickly as possible. Getting NATO on board and knowing that NATO forces were going to go in later made it easier to sell the policy to the US government-and particularly to the Joint Chiefs." 130

\footnotetext{
125 Slocombe, interview. See also Clark, Waging Modern War, 137, 142, 163.

126 Quoted in Bradley Graham, "Much Misgiving About Airstrikes," Washington Post, 7 October 1998.

127 Weisman, interview.

${ }^{128}$ Albright, Madam Secretary, 383.

${ }^{129}$ Alejandro Wolff (executive assistant to the US secretary of state, 1998-2000), interview by author, 31 March 2010. See also Halberstam, War in a Time of Peace, 388.

${ }^{130}$ Halperin, interview (emphasis added).
} 
For some time in 1998, the State Department also considered the possibility of seeking approval for the use of force from the UNSC, based on the expectation that a Security Council mandate would make it easier to garner European support. ${ }^{131}$ However, by mid-July 1998 the administration concluded that given Russia's recalcitrance, "efforts to achieve a United Nations Security Council Resolution under Chapter VII would be counterproductive." 132 During subsequent months, Washington focused its multilateral diplomatic efforts almost exclusively on the Atlantic alliance. In late August 1998 the NSC Deputies Committee, in which senior officials below cabinet rank typically work out the details of US national security policy, concluded that "the first round of air strikes should not be launched without agreement in principle on a substantial follow-on package. With this in mind, [it was decided that] Secretaries Albright and Cohen ... will contact their [NATO] counterparts to ... build consensus for substantial air operations." 133

It took another several months, until 23 January 1999, for the military leaders to consent to a strategy based on airstrikes, contingent on NATO's final approval. ${ }^{134}$ By then, the deteriorating humanitarian situation in Kosovo had strengthened NATO's resolve, and a meeting of the Balkans Contact Group, a transatlantic diplomatic forum, on 22 January persuaded the JCS that the Western Europeans could indeed be relied upon to contribute the majority of stabilization troops. ${ }^{135}$ The NAC then endorsed the use of airpower on 30 January. ${ }^{136}$ After the failure of a last-ditch diplomatic effort in Rambouillet, France, NATO commenced its air campaign on 24 March. $^{137}$ As the political scientist Michael Beckley puts it, the support of America's principal military alliance "encouraged US military action by making it less costly." 138 Soon after Milosevic yielded to NATO's demands in early June, Washington's European allies then publicly reconfirmed their willingness to shoulder most of the postwar burden. ${ }^{139}$ Washington's pursuit of a consistently multilateral approach over Kosovo bore the intended fruits: over

\footnotetext{
${ }^{131}$ Peter Burleigh (acting US permanent representative to the United Nations, 1998-99), interview by author, 3 April 2010.

132 National Security Council, "Summary of Conclusions of Meeting of the NSC Principals Committee," 15 July 1998 (document released pursuant to MDR request 2009-0983-M, submitted by author).

133 National Security Council, "Summary of Conclusions of Meeting of the NSC Deputies Committee," 26 August 1998 (released pursuant to MDR request 2009-0983-M, submitted by author).

${ }^{134}$ Kaufmann and Weisman, interviews. See also Albright, Madam Secretary, 395; Sciolino and Bronner, "Crisis in the Balkans"; Daalder and O'Hanlon, Winning Ugly, 72.

135 Weisman, interview. See also Ray Moseley, "Diplomats Approve Peace Plan For Kosovo," Chicago Tribune, 23 January 1999.

136 NAC, "Statement on Kosovo," 30 January 1999, available at http://www.nato.int/DOCU/pr/1999/ p99-012e.htm.

137 Daalder and O'Hanlon, Winning Ugly, 77-89.

138 Michael C. Beckley, "Entangling Alliances? Assessing the Security Risks of America's Defense Pacts," International Security 39, no. 4 (Spring 2015), 45.

139 Anne Swardson and Charles Trueheart, "Europeans Assume Lead in the Balkans," Washington Post, 5 June 1999.
} 
the following years, the United States never contributed more than sixteen percent of troops to the international stabilization force. ${ }^{140}$

\section{CONCLUSION: ARE THE GENERALS “OUT OF CONTROL”?}

Civilian policymakers debating the use of force differ significantly in their attitude toward multilateralism depending on their sense of urgency, their strategic assessment, and their ideological background. Consequently, simply looking at policymakers' attitudes does not allow us to account for a strikingly consistent pattern: since the end of the Cold War, US humanitarian military interventions have either been carried out multilaterally, with IO approval, or they have not been carried out at all. This article has argued that whatever else may motivate civilian policymakers to seek UN or NATO approval for humanitarian interventions, such approval is necessary to mollify US military leaders and overcome their veto. Evidence that the generals, as political realists, value international burden sharing and can steer US policy on humanitarian intervention toward the UNSC or NAC buttresses claims that support for multilateralism need not necessarily flow from lofty internationalist beliefs but may just as well result from pragmatic concerns with capability aggregation and limited liability in foreign affairs. ${ }^{141}$

The argument developed in this article can also illuminate instances of US nonintervention. When civilian policymakers advocate the use of force for humanitarian purposes, but they are unable to secure IO approval and the situation does not clearly threaten US national security, senior uniformed leaders can be expected to veto the use of American force. Two examples may help to illustrate this. In 2005 and 2006 civilian policymakers advocated the deployment of American combat troops on a humanitarian mission to Darfur, and President George W. Bush was reportedly sympathetic to the idea. Members of the JCS, however, were adamantly opposed: they estimated that the mission would require up to 120,000 US troops and emphasized the risk of a costly, open-ended commitment. ${ }^{142}$ Seeking to address some of the military's concerns, the president, together with Secretary of State, Condoleezza Rice, advanced the idea of "NATO stewardship" for Darfur. ${ }^{143}$ But the administration was unable to obtain NATO's support, and the generals'

\footnotetext{
${ }^{140}$ Woehrel, "Future of the Balkans," 11.

141 See Bruce Jentleson, "Tough Love Multilateralism," Washington Quarterly 27, no. 1 (Winter 2003): 5-24, esp. 8-9.

${ }^{142}$ For a useful discussion see Rebecca Hamilton, Fighting for Darfur: Public Action and the Struggle to Stop Genocide (New York: Palgrave Macmillan, 2011), chap. 6.

143 Jendayi Frazer (assistant secretary of state for African affairs, 2005-9), interview by author, 27 January 2011. See also Bradley Graham and Colum Lynch, "NATO Role in Darfur on Table," Washington Post, 10 April 2006.
} 
objections eventually persuaded the civilian leadership that direct US military intervention without solid multilateral backing was unfeasible. ${ }^{144}$

The generals' opposition also played a key role in keeping the United States on a path of nonintervention as a genocide unfolded in Rwanda in the spring of 1994. In late April 1994, reacting to reports of spiraling ethnic violence, midlevel officials from the NSC staff and the State Department floated the possibility of a US humanitarian intervention in Rwanda. ${ }^{145}$ Yet declassified documents show that their uniformed counterparts on the Joint Staff were "in stiff opposition," emphasizing the risks of intervention and "strongly object[ing] to signing up for open-ended missions that could lead to ... troops being in life-threatening situations." 146 Given the highly volatile situation on the ground and the fact that there was little enthusiasm among other members of the UNSC for authorizing a peace-enforcement operation and contributing troops, no high-ranking US official was willing to challenge the military and push for intervention. ${ }^{147}$ Only in late July 1994, after the ethnic violence in Rwanda had abated, did the JCS consent to the deployment of American troops to the region as part of a UN-sponsored relief effort, having obtained credible assurances that a follow-on multilateral mission would soon take over. ${ }^{148}$

In several ways, the senior military officers appear to embody a longstanding concern of American political realism with restraining the interventionist impulses of liberal US civilian elites. ${ }^{149}$ It bears emphasizing, however, that the military can tilt the bureaucratic balance of power toward nonintervention and thus veto the use of force only as long as the civilian leadership is divided and the president remains uncommitted. If President Clinton and most of his civilian advisers had been determined to intervene in Rwanda, the military would almost certainly have followed civilian orders. The military leaders are unlikely to oppose publicly a particular intervention after the president takes a final decision to intervene. ${ }^{150}$ The concerns of some

\footnotetext{
${ }^{144}$ Frazer, interview. See also Hamilton, Fighting for Darfur, 77-79.

145 Power, Problem from Hell, 364-70.

146 Office of the Secretary of Defense, "Rwanda Interagency Telcon," memorandum of conversation, 11 May 1994. See also Office of the Secretary of Defense, "Discussion Paper: Rwanda," 1 May 1994, available at www.nsarchive.org.

${ }^{147}$ Power, Problem from Hell, 370-73. On the lack of international support for peace-enforcement in Rwanda, see also Wheeler, Saving Strangers, 223-28.

148 Kross, interview. See also Power, Problem from Hell, 380-81.

${ }^{149}$ Michael C. Desch, "Hartz, Huntington, and the Liberal Tradition in America: The Clash with Military Realism," in American Civil-Military Relations, 91-111. See also Stefano Recchia, "Restraining Imperial Hubris: The Ethical Bases of Realist International Relations Theory," Constellations 14, no. 4 (December 2007): 531-56.

150 The military's understanding from mid-2002 onward that President Bush was determined to intervene in Iraq, for instance, partially explains why, although the military had serious reservations, there was little military pushback in the run-up to the 2003 Iraq War. See Stefano Recchia, Reassuring the Reluctant Warriors: US Civil-Military Relations and Multilateral Intervention (Ithaca, NY: Cornell University Press, 2015), chap. 6.
} 
analysts that the US military leaders may be "out of control" are therefore exaggerated. ${ }^{151}$ Although the US military has significant leverage over policymaking on the use of force, there is no serious threat to the principle of civilian control in the United States. Indeed, the military's leverage can be seen as aligning with the American Founding Fathers' intent to check and balance political power, thus fostering deeper deliberation and making it more difficult for controversial use-of-force policies to go forward without broad-based domestic support.

\section{ACKNOWLEDGMENTS}

Research on this article was supported by a fellowship in foreign policy that the author held at the Brookings Institution in Washington, D.C. The author would like to thank Mike Beckley, Richard Betts, Stefano Costalli, Michael Doyle, Mette Eilstrup-Sangiovanni, Payam Ghalehdar, Marina Henke, Bob Jervis, Miles Kahler, Michael O'Hanlon, Joe Parent, Tonya Putnam, Pascal Vennesson, Joel Westra, and two anonymous reviewers for their helpful comments on previous versions of the article. The usual disclaimers apply. Open access publication was made possible by a "Marie Curie" Career Integration Grant from the European Commission.

151 See Richard H. Kohn, "Out of Control: The Crisis in Civil-Military Relations," The National Interest 35 (Spring 1994): 3-17. 